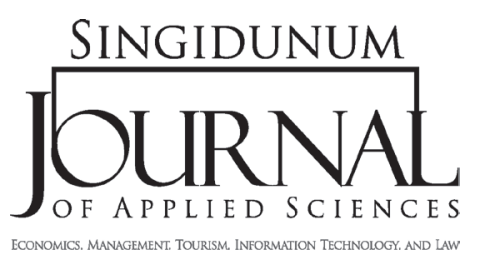

SINGIDUNUM JOURNAL 2013, 10 (1): 1-10

ISSN 2217-8090

UDK: 005.336.3:005.35; 005.336.1:334.72

DOI: $10.5937 /$ sjas1301001C

Original paper/Originalni naučni rad

\section{ANALYSIS OF THE APPLICATION OF THE CONCEPT OF CORPORATE SOCIAL RESPONSIBILITY IN LOCAL BUSINESSES}

\author{
Milenko Ćeha* \\ Ministry of Interior of the Republic of Serbia \\ Blvd. Mihajla Pupina 2, Belgrade, Serbia
}

\section{Key words:}

corporate social responsibility, business excellence, competitiveness, quality, business.

\section{INTRODUCTION}

Modern society is placing increasing demands on companies to take over full moral and legal responsibility for their actions, especially when it comes to the protection of consumers' interests and environmental protection. Modern business philosophy assumes that an organization must be responsible for its actions and deeds that affect all active members of the community. Companies that want to be competitive should satisfy the interests of a large number of interest groups operating within a particular business environment.

Corporate ethics has become an important requirement in every business, from the management boards of the world's largest corporations to classrooms in business schools and universities world wide. Nowadays, a large number of huge corporations are faced with having to meet the increasing requirements for the protection of the environment. Therefore, they should incorporate thinking based on those requirements when managing their business.

In terms of changing attitudes of the modern businessman towards the principle of social responsibility, sir Richard Branson (2010, p.7), British entrepreneur and innovator and the owner of The Virgin Group best said: "As a capitalist I was confronted with an unpleasant and difficult question: 'Do I cause damage?' After some careful research and investigation, I discovered that it is in fact possible to be a capitalist and still maintain the philosophy of environmental protection I have already been practicing for some time. I created the expression Geja Capitalism as a principle, slogan, and directive for progress." 
Today we hear more and more about corporate social responsibility (CSR). It represents the commitment to advancing the well being of society through discretion business practices and contributions at the expense of company resources (Kotler and $\mathrm{Li}, 2007$, p.3). The keyword of this definition is discretion. It represents a willful commitment of the organization to choose and apply business practices that contribute to the community. The concept of corporate social responsibility is now standardized and represents an integral part of integrated management systems.

One of the most significant issues in domestic economy, which contributes greatly to the bad market performance of our companies on the international market, is the inadequate use of modern methods and techniques of management. This refers in the first place to knowledge necessary for the efficient business management. One possible variant for progress in business is the process of implementation of foreign experience and the expansion of knowledge with the aim of improving the quality of business and achieving competitiveness.

Factors such as the insufficient experience of a company regarding the application of modern management concepts and techniques, lack of respect towards foreign experience, inadequate approaches to marketing, as well as little or no knowledge of marketing technology, lead to the fact that domestic companies cannot keep up with the international competitors. Acquiring knowledge in line with the world experience represents a significant factor for business advancement of the domestic companies.

The question regarding the need for a strategic shift in the attitudes of local managers towards accepting the necessity for continuous improvement of labor productivity and business, based on the application of knowledge, is not a matter of daily politics but of business philosophy changes. The purpose of education in the field of management skills and techniques is to acquire knowledge necessary for the successful management of a company and/or its operations with the aim of increasing the productivity of both labor and knowledge.

One of a series of problems of the local business organizations, which is distinguished by its importance, is raising the level of social responsibility in everyday business practices. The problem of applying the concept of corporate social responsibility (CSR) in domestic business organizations has not still been understood in an adequate manner, thus making the question of CSR a matter of management standards set by the International Organization for Standardization.

\section{ANALYSIS OF MAJOR FACTORS AFFECTING THE OPERATIONS OF A MODERN ORGANIZATION}

New economic conditions require new approaches to the study of organizational management, in addition to business practices. Changes in the market area most directly affect the way of thinking related to the company management. Also, the changes in science and technology are quickly evolving - for instance, a product's lifetime in microelectronics is shortened to only 18 months. According to Kotler $(2004$, p.156), any new technology is a force of creative destruction - the greatest danger for any company is not its competition, but the use of new technological solutions.

An organization striving to be successful and to maintain and develop a competitive advantage in the market must be willing to learn. This means that a company must keep up with changes not only on the market, but also in science, in order to achieve business excellence. The companies must monitor not only the direct competitors, but also those who are the best in their fields, even if they are not direct competitors.

Business excellence means that companies should constantly work on the implementation of the quality of business of the organization, which is based on the increase of labor productivity and knowledge of every employee. Japanese companies were among the first to accept the need for action in order to build a successful future for themselves. The current activities of an organization result in effects that are visible not only in the present, but that can significantly affect the sequence of future events. One of the basic postulates of Japanese companies is proactivity. Namely, responsibility for one's own task is the imperative for every individual, the entire organization, as well as for all businesses and other organizations in an economy.

In information society, knowledge becomes the basic resource of business, which makes it possible for the remaining three resources, consisting of manpower, capital, and natural resources, to be productive. Knowledge becomes a tool, a means for accomplishing results in social and economic development. It is understood in terms of economic knowledge, 
that the management will confront usual prejudices - reorganization, reengineering, new stylization, redefinition of own goals, searching for new purpose, refocusing, revitalization, and revision (Tiesen et al. 2006, p.159).

Today's business can be observed as enterprising economy. This expression dates from the early 1990 's, and it is concerned with the reality of modern economy in which dominates enterprise management. The existence of an enterprising economy makes way for new applications in the field of management - in new companies, small companies, non-economic activities, small businesses, and in the domain of system innovations. In an enterprising economy, all organizations, regardless of the type of the task, also have to act enterprisingly and implement the basic postulates of enterprising in their organizational structure.

According to Adizes (2006, p.56), enterprising is a function of creativity and taking risks. According to some modern opinions, an entrepreneur no longer has to be defined as an individual who is the owner of a business. The entrepreneur can be a single person who is employed by an employer, but who must possess skills characteristic of entrepreneurial conduct. According to Drucker (2003, p.173), jobs in an organization have to run in an enterprising manner, in order for a company to become an enterprising organization. In that sense, a model is developed for corporate enterprise, which gives team work potential, and in turn its members are motivated to work on achieving success and accepting risks.

Modern society is based on the production and distribution of information, which in turn demands a high level of awareness, education, and the use of information pertaining to all interest groups in an area (participants). Information technology makes it possible for the communication development process to reach a global level in real time, and at the same time reduces the floating information. That means that business organizations have to become aware of the demands of all segments of the public. Furthermore, it means that business organizations have to establish an adequate level of understanding with all segments of social and business areas. As can be observed, the level of understanding must be further developed and raised to a higher standard for every subsequent plan-cycle in order to maintain a successful business organization.

Every business organization has significant influence on the environment in which it operates. An organization affects the environment economically, technically-technologically, ecologically, culturally, and in a social sense. Moreover, the organization has to carry out substantial actions for increasing the positive influence on its environment for each of these fields. According to Miljević (2008a, p.173), modern nature of working in post capitalistic organizations in the world of business, which is based on scientific and technical knowledge and their results, has been accumulated and created a new world - a world of things. This new world of things demands new business ethics - far-reaching responsibility ethics - no matter if it is influenced by non-human or human nature.

\section{CORPORATE SOCIAL RESPONSIBILITY AND MODERN BUSINESS}

Social responsibility permeates modern business. Trends in the development of the concept of business ethics and the implementation of this practice to the organizational structure of a company have been occurring for over three decades. During the time-frame of the twentieth century, between the two world wars, the International Chamber of Commerce made a certain code of conduct for this specific field of business (e.g. International Code of Conduct in the field of economic advertising was passed for the first time in 1937 by International Chamber of Commerce in Paris).

Japanese managers have made a significant contribution to the development and application of business ethics. Namely, during the fifties, they actively started developing concepts for quality management based on a range of American management systems and Japanese philosophical principles, such as kaizena. In this way, Japanese companies developed a permanently evolving system for business productivity, concern for human resources and partners, and, on an international level, they managed to avoid competition between domestic companies - compete, yes, but exclusively in their domestic market. The Japanese model for developing business quality, in addition to managing to be perceived in a broader perspective, was copied in the USA and in Europe at the end of the eighties. Since then, it has become one of the most dominant management models and has, at the same time, become a base for the wider acceptance of corporate ethics.

According to Drucker (2003, p.53), the main responsibility of one professional was clearly defined 
in Hippocrates's oath, in an ancient Greece two and a half thousand years ago: "Primum non nocere" above all, do not harm anyone consciously. A professional is a private person, but also a public person, in the sense that the well being of the client sets limits to his actions and words - the principle "do not cause damage consciously" is in fact the basic rule of professional ethics, but also a basic rule of ethics for public responsibility. Fayol (2006, p.45) listed fairness (11th principle) as one of the 14 principles of administration, "Business ethics is defined as a set of principles, norms and standards of behaviour used for guiding an individual or a group in business, or as a group of principles and standards leading to the acceptable conduct in the business world. In the most general sense of the word, it is understood as moral behavior and actions" (Miljević, 2008, p.27).

Corporate social responsibility (CSR) is a concept framework, in which companies integrate social interests and challenges concerning the environment and their business in integration with all stakeholders by freewill.

State administration in the most developed countries around the world has, for the last three decades, been developing legislations in order to prevent the degradation of the environment and natural resources, improve and protect the environment, and define specific guidelines for sustainable development on a global level. Business entities have to satisfy the goals of a greater number of interest groups in their environment. Modern society is increasingly signifying the demand for companies to define their social responsibility.

Social responsibility (SR) in business is related to the obligation of the company and other business organizations to increase their positive influence and reduce their negative acting on society. According to Eric Reinert (2010, p.200), a Norwegian economist, capitalism is based on own interests, due to the fact that private vices can be converted to public benefits. Conclusion of debt debate during the time of enlightenment was that the best warranty for public sector was to ensure that own interests matched with social interests. Successful capitalists earn money through imperfect competition. When this imperfect competition is realized through new technology, as is often the case, it is possible to observe the relation between one's own interests and social interests.

According to the World Council for Sustainable Development, corporate social responsibility represents a company's commitment to contribute to sustainable economic development through cooperating with the unemployed, their families, the local community, and society in general in order to improve the quality of their lives. In the Green Book, the European Union states that being socially responsible is not only to respect legal obligations, but to go further than the mere compliance with the law and to invest even more in human capital, the environment, and relations with stakeholders.

Thus, to be socially responsible means to look after the needs of individuals as well as of the community - invest in health-care, human resources, culture, and healthy environment. Simply put, it means to develop human relations with different social subjects.

Generally speaking, CSR assumes that for the profit they have made, companies are responsible not only to their shareholders, but also to the individuals and groups that are in any way affected by that profit.

Corporate social responsibility represents determination for the development of the well-being of a community through discretion business practices and contributions at the expense of company resources (Kotler and Li, 2007, p.3). The keyword of that definition is discretion. It refers to the goodwill of the organization and its decision to choose and use business practices that contribute to the community. Some reasons for using and developing corporate social responsibility are as follows: increasing market participation, strengthening the position of brands, strengthening corporate image, improving the ability to attract and motivate employees, reducing operating costs, and increasing attractiveness for investors.

According to some opinions, we can today observe six social initiatives that act upon the domain of corporate social responsibility:

1. Promoting social goals,

2. Marketing associated with social goals,

3. Corporate social marketing,

4. Corporate philanthropy,

5. Volunteer work for the community,

6. Socially responsible business practices (Kotler and Li, 2007, p.3).

Promoting social goals implies that a company provides funding, in-kind contributions, or other resources, to develop awareness of social order, or to collect certain funds for the benefit of this social 
goal. Marketing associated with social goals means that a company is obliged to associate a certain percentage of income, realized by selling products or services, with a certain social goal. Corporate social marketing means that a company facilitates the development and/or implementation of a campaign for a change in conduct towards the progression of health, security, environment, or well being of the community. Corporate philanthropy is a practice in which a company directly contributes to a charity or social action; this is mostly given in the form of grants as cash or through in-kind donations. Volunteer work for the community means that a company upholds and encourages its employees, just as employees at partnership organizations volunteer to help local social organizations and projects. Socially responsible business practices can be understood as situations in which a company, in its sole discretion, adopts and implements business practices that support a cause, which should improve the quality of life in the community and the protection of the environment.

\section{THE ROLE OF CORPORATE SOCIAL RESPONSIBILITY IN ACHIEVING BUSINESS EXCELLENCE}

The latest trend in the development of quality management is the integration of management standards and the process of organizational management. One of the practical ways to implement corporate ethics and corporate social responsibility is the implementation of integrated management systems (IMS). The International Management Standards that are published by ISO (such as ISO 9000, ISO 14000, ISO 18000) incorporate elements related to social responsibility. In addition, the standard ISO 26000, which is directly related to the question of corporate social responsibility, is being developed. The implementation of an integrated management system allows for a reduction in the time necessary to create a concept of total quality of management - TQM, which creates conditions for companies in less developed countries, in response to the demands of the international standards, to build a business system that allows the formulation of world-class products and the implementation of business excellence. Applying the concept of IMS may be of great importance for companies coming from countries undergoing transition. Instead of the lengthy creation process of TQM, it is possible to achieve business excellence in a shorter period of time through the application of modules, one by one, into integrated management systems in compliance with the requirements of international standards ISO 9001, ISO 14001, ISO 18002 and SA 8000. Each of these standards incorporates some of the assumptions of the concept of corporate social responsibility, and standard SA 8000 is directly related to the development of this principle. Social Accountability 8000 (SA 8000) represents an international standard for social responsibility created by CEPAA (Council on Economic Priority Accreditation Agency) and is intended to provide an ethical source for products and services. This standard is voluntary in nature and can be applied to any company regardless of its size or activity. Also, this standard can replace or be a supplement to companies or industries with a specific code for social responsibility. International standard SA 8000 was created in 1997 and revised in 2001. The Standard SA 8000 is based on ISO 9000, but its goal is to improve working conditions in factories all over the world. The difference between these standards lies in the fact that SA 8000 includes characteristics required in addition to the system. Namely, requirements in SA 8000 require from the employer not to exploit his employees but to provide a safe working environment, not to employ children or force anyone to work, and not to demand from employees to work more than 48 hours per week. SA 8000 is based on nine elements, as follows:

1. Child labour,

2. Forced labour,

3. Health and safety,

4. Freedom of association and right to a collective agreement,

5. Discrimination,

6. Discipline,

7. Working hours,

8. Compensation,

9. Management system.

The elements of these standards demand from the employer not to hire children under 14 (according to the criteria in the UN, children under 14 should not be employed), not to apply forced labor (for example, worker has to work overtime, otherwise he will be fired), and to organize in such a way so that the processes are in accordance with the need to protect the worker's health. The employer must ensure the employee the freedom to join trade union organizations and prevent various forms of discrimination against workers (gender, religion, 
race, age). The employer must establish an adequate level of labor discipline that does not violate the dignity of the individual worker, and working hours that are in accordance with International Labor Organization (ILO) and the conference of the Free Labor Union. The employees should be adequately rewarded for their work and their employer must provide such a management system that complies with the standards of the International Management Standard.

In the policy document "ISO Horizon 2010 standards for sustainable world", Central Secretariat ISO identified as key elements: urgent approximation towards development of social responsibility, covering aspects of the economy, society, and environment, in which all participants in society have their role, and in addition, companies and other organizations create new commitments. The International Organization for Standardization defined a series of standards ISO 26000 and provided guidelines for social responsibility (SR) at the international level. Standard ISO 26000 is directed towards all kinds of companies, in public and private sectors, in both developed and transitioning countries. Standard ISO 26000 has added value to the existing initiatives for SR by providing harmonization and global guidelines based on an international consensus by the leading representatives of professional groups of stakeholders, thus promoting the application of the best practices of SR around the world.

\section{CORPORATE SOCIAL RESPONSIBILITY AND COUNTRIES IN TRANSITION}

The question of the establishment and development of corporate social responsibility is concerned with achieving competitiveness in all developed countries around the world. Nowadays, CSR is a ubiquitous concept which allows companies from developing countries to maintain and develop a competitive position on the global market, to develop understanding with stakeholders in the region. Companies from the countries in transition still have problems with the establishment of CSR. The problems that economy undergoing the process of transition faces represent the consequences of incompleteness of the socialist economic system. Transition represents the transformation of a national economy, from a centrally planned economy (or socialist economy), to a market economy. Transition represents ownership, a structural and institutional change in the manner of doing business, and improvement of the efficiency of business in accordance with the requirements of the international market and global market trends.

The transition from planned to market economy requires time. A generally accepted theory is that a "general model" of transition does not exist - every national economy has its own particular way of determining the pace of economic change and the hierarchy of priorities that guides the process of transition. Improving competitiveness of one national economy in the global economy is closely related to the economic development, the increase of employment, and effective earning which is based on the imperative to increase productivity.

On the other hand, the global economy is reality, and the business imperative in the global economy is permanently increasing productivity for all keybusiness resources (primarily labor and knowledge). The inadequate use of knowledge represents the biggest problem for most companies coming from countries in transition and with a capital of domestic origin. Namely, habits inherited from the past influence the inappropriate treatment of education; especially knowledge - not enough attention is paid to the fact that knowledge represents the basic business resource that should be constantly improved. Specifically, this means that companies from transitioning countries still do not apply all foreign business experience and modern management techniques in order to constantly improve their business.

When it comes to the implementation of CSR, the situation is particularly unfavourable. Ethical principles in business are still developing. Very few companies apply the concept of CSR. Companies usually choose corporate responsibility only declaratively, while their business is solely based on personal interests. The public interest is only a declarative category.

A particular problem for countries in transition are branches of multinational and transnational corporations that behave inappropriately in relation to the developing market and that generally avoid applying the integrated model of business ethics in markets in transitioning countries. As a result, multinational and transnational corporations make higher profits on the one hand and delay the development of local markets on the other.

When it comes to competitive relationships, free competition is only declaratively understood, while in most countries in transition the state monopolies still prevail (public companies). There are companies in transition countries that rely on close ties 
with state administration when achieving their own interests.

The issue of corruption is certainly the one of the most important issues concerning the development of market mechanisms in countries in transition. Corruption is more obvious and present in countries in transition, due to the underdevelopment of market mechanisms, the degree of economic freedom, as well as the underdeveloped democratic system. The democratic system of government, market mechanisms and legal infrastructure which is adequate to economic and social development, are the basic requirements for minimizing corruption.

The field of corporate philanthropy is particularly suitable for corruptive actions in countries in transition. Namely, undeveloped market mechanisms and the lack of an adequate tax system that clearly distinguish philanthropy from other benefits, make it possible for certain companies from transition countries to use this form of CSR in order to achieve their personal profit interests (the financing of a certain group with the aim to achieve profit). Particularly interesting is the case of lobbying, done by companies coming from the most developed countries of the world, which finance certain foundations that are turned to political education (politicians, offspring of political parties, young experts, etc.). By financing certain foundations, multinational and transnational corporations attempt to achieve their own economic interest by using individuals, or groups, who have been officially financed by foundations (training, scholarship abroad, study visit abroad, etc.).

Competition from abroad is looking for a way to avoid the mechanism of free competition in cooperation with quasigovernment companies or public companies, to enlarge profit and develop the market. In most countries in transition, consumers are inadequately protected, from both domestic and foreign producers. It is well-known that some large multinational and transnational corporations have a higher quality products for developed markets and lower quality products for markets in the transition countries.

The issue of the protection of the environment is still insufficient even though there is a legal infrastructure. The reason for that is that there is not enough experience in its application, and in some cases it is deliberately avoided. Companies from developed markets buy companies from the so-called "dirty technology" sectors in transition countries to take advantage of the existing resources and quali- fied workforce, but also slight legislations in this field. The situation is even more critical for the same companies that were purchased by local entrepreneurs, who are doing their best to avoid legal norms in the field of environmental protection.

Workers are particularly targeted in countries in transition. Undeveloped social infrastructure, the absence of social dialogue institutions, and atrophied unions affect the domestic and foreign entrepreneurs' behavior very inappropriately regarding the globally accepted standards in the field of worker's right.

In all developed economies, unions represent the crucial factor for employment and problem solving in the domain of employment. On the other hand, in transition countries, the underdevelopment of union organizations is evident, which in turn has negative impact on the protection of worker's rights, especially in the early stage of the transition process. It has also been observed in the first phases of the transition process that some union organizations look much more like political organizations than like organizations that should represent worker's interests. Unions must have a significant role in the process of privatization in order to protect workers and their rights. The chamber system includes almost $2 / 3$ ownership (state property), and with its members (mostly comprised of social companies) is currently exempt from acting in tripartism.

The near future already points out the need to include the elements of CSR in business practices in companies from transition countries. These companies are expected to take part in fair competition, the protection of consumers' interests, the protection of workers' rights etc. When speaking about competition and elements of business ethics, all developed markets require of companies from countries in transition to have at least one, and often multiple, certificates of the standards applied in management (quality management system, environmental management, management of health and safety, etc.). All exporters and food producers from countries in transition, wishing to export to the EU, must have food safety certification (HACCP), while products incurred as a result of certain treatments that may be harmful to the environment require certification of environmental management (ISO 14000). The question here is not whether companies from transition countries need to deal with the implementations of business ethics, but how fast they can keep pace with the developed world. 


\section{ANALYSIS OF APPLICATION OF THE CONCEPT OF CORPORATE SOCIAL RESPONSIBILITY IN LOCAL BUSINESS}

The concept of CSR has been applied and developed in local business organizations from the beginning of the transition process. The corporate social responsibility awareness is present in Serbia, but on the level of concept in formation, which is just beginning to be recognized as important and socially desirable, rather than on the level of realized behavior with which we have experience. There are significant barriers when it comes to promoting the idea: many companies still do not understand the long-term benefits that bring forth socially responsible access. Namely, many businessmen and entrepreneurs believe that they do not have enough of the required resources or knowledge at their disposal to engage in various strategies. The concept of CSR is developing in our country, and the major carriers have so far been NGOs (e.g. Smart Collective). In the Serbian Chamber of Commerce (which adopted the codex of corporate behavior and business ethics and participates in awards for CSR), the media (B92, an economist magazine group), and scientific institutions (universities and social institutes), have been adopting CSR, but in practical sense, CSR has been widely applied in companies with foreign capital.

Certain elements of the CSR concept had been applied, both in the time before the transition process began and several decades before that. One of the most significant forms of CSR applied in Serbia was corporate philanthropy.

Although certain forms of actions existed before transition, the concept of CSR has actually been applied only for the last ten years and primarily by large local government systems, such as EPS and Telecom Serbia etc., and in corporations where the foreign capital prevails. The reason for this is the fact that many local companies belong to the group of small- and middle-sized companies, which by definition have no funds for investment in this area, and no knowledge. Foreign Corporations have the funds and the human resources necessary for the implementation of activities in the domain of CSR, and they also realize CSR for their own goals related to market development.

On the other hand, it is observed, in theoretical and methodological terms, that the concept of CSR is still under study - it is mainly studied in the thematic areas of management and corporate ethics, or possibly integrated management systems. The selfstudy of CSR concept has not yet reached the local scientific community. Regarding this, there is a need for a more comprehensive study of this important area that touches both management and business ethics and quality management.

Research on the application of the concept of corporate social responsibility in companies operating in the domestic market was undertaken from June to October 2010 on the territory of Serbia, in order to obtain the opinion of managers of the companies regarding the implementation of the concept of corporate social responsibility. Some of the most important results of the research are as follows:

- The managers emphasize the following factors as the basic one for business advancement: upgrading employees' skills $-27.6 \%$, improvement of the quality of business $-17.3 \%$, applying modern methods and techniques of management $11.2 \%$, development and application of information technology $-10.2 \%$, increasing business productivity $-8.2 \%$,

- The essential elements for the development of competitiveness of local companies are as follows: continuous improvement of skills and knowledge of the management and employees $22.2 \%$, applying modern methods and techniques in management $-21.2 \%$, standardization of the quality of business $-15.1 \%$, purchasing modern technological solutions and equipment $-12.1 \%$, the importance of investment in marketing $9.1 \%$,

- Major obstacles in development of competitiveness for local companies are: shortage of financial capital $-24.7 \%$, lack of knowledge $-21.6 \%$, obsolete equipment and technology $-15.7 \%$, lack of resources $-8.8 \%$, insufficient stimulation of the business environment $-8.8 \%$,

- The most frequent activities within the domain of CSR in the analyzed business organizations are as follows: socially responsible business practices $-37.7 \%$, promoting social goals $-26.4 \%$, corporate social marketing - $15.1 \%$, corporate philanthropy $-9.4 \%$, marketing connected to social goals $-5.6 \%$.

Most of the respondents or more precisely $81.25 \%$ of them believe that there are local companies that can be characterized as business executive organizations. Taking into consideration all the limitations this model reveals, factors for the improvement of business and elements for the development of com- 
petitiveness as well as social initiatives in the field of CSR which are to be applied, local companies can achieve certain level of business excellence.

Based on the research results, a model has been developed for the improvement of CSR in local business organizations and it includes the following elements: satisfying interest groups, basic factors to improve business, necessary elements for the development of competitiveness in local companies, major obstacles in developing competitive local companies, process of organizational management, implementation of CSR activities with the aim to satisfy interests groups, analysis of the fulfillment of the requirements of interests groups, and permanent improvement of business.

This model points out the need to build strong relations between the application of integrated management systems, the continuous improvement of the knowledge of employees and managers, productivity, and business excellence. Quality and CSR are closely connected - the concept of integrated management systems contains essential elements of corporate social responsibility, the quality education and application of the concept of quality directly develops the concept of CSR in local companies. The implementation of social initiatives in the field of CSR by a feedback system, and continuous improvement of business, increases satisfaction of interests groups in the environment, and thus contributes to the success of the business.

\section{CONCLUSION}

Modern business requires new approaches to the management of an organization. Social responsibility is the supreme principle in modern business. All the corporations that are successful in global proportions are socially responsible organizations. Business practices of the world's most successful corporations show that there is a high degree of correlation between the positive opinions of interest groups within the company and the quality of business. Companies that actively and continually apply modern methods and management techniques have a much better chance of strengthening their competitiveness on the global market and acquiring a stable market position with perspectives for further market growth. Nowadays, the concept of social responsibility represents one of the most important principles of modern business, which has a direct influence on the developing market position of a company and on strengthening the competitiveness of an organization. Making a profit today is closely related to social responsibility and socially responsible business practices.

A recent analysis of the local market shows that all socially responsible companies are at the same time leaders in the field of quality. The improvement of competitiveness of local companies is under direct influence of the development of the concept of quality management and corporate social responsibility. Local companies need to clearly design their own development strategy in accordance with the European and global integration trends, and the application of modern methods and techniques of management, as integrated management systems, which represents the basic assumption of successful market development. Applying the concept of corporate social responsibility may be of great importance for the companies coming from transition countries. CSR allows for improvement and competitiveness in the global market.

The most important trends in the development of competitiveness of local business organizations are the adequate use of knowledge in organizations, the development of institutions in a business environment, and the development of legislation. Operation of domestic companies must be based on the application of management techniques that support competitiveness, innovations and flexibility, and the fact that CSR concept occupies a very important place.

\section{REFERENCES}

Adižes, I. (2006) Upravljanje promenama: moć uzajamnog poštovanja i poverenja u privatnom i porodičnom životu, poslu i društvu. Novi Sad: Adizes. (in Serbian)

Brenson, R. (2010) Ništa nije nemoguće. Belgrade: Plato. (in Serbian)

Draker, P. (2003) Moj pogled na menadžment. Novi Sad: Adizes. (in Serbian)

Fajol, A. (2006) Opšti industrijski Menadžement. Novi Sad: Adizes. (in Serbian)

Kotler, F. (2004) Marketing od A do Z. Novi Sad: Adizes. (in Serbian)

Kotler, F., Li, N. (2007) Korporativna društvena odgovornost: učiniti najviše za svoju kompaniju i za izabrani društveni cilj: najbolje prakse vodećih kompanija. Belgrade: Hesperia: Faculty of Economics, University of Belgrade. (in Serbian) 
Miljević, M. (2008) Poslovna etika i komuniciranje. Belgrade: Singidunum University. (in Serbian)

Reinert, E. (2010) Spontani haos: ekonomija u doba vukova. Belgrade: Čigoja štampa. (in Serbian)

Tisen, R., Andriesen, D., Depre, F.L. (2006) Dividenda znanja. Novi Sad: Adizes. (in Serbian)

\section{ANALIZA PRIMENE KONCEPTA KORPORATIVNE DRUŠTVENE ODGOVORNOSTI U DOMAĆIM POSLOVNIM ORGANIZACIJAMA}

\section{Rezime:}

Moderno društvo zahteva veliku odgovornost i doprinos svih svojih članova. Društvena odgovornost u poslovanju se odnosi na obavezu kompanija i drugih poslovnih organizacija da povećaju pozitivni uticaj a smanje negativni uticaj na društvo. Korporativna društvena odgovornost podrazumeva dobrovoljno opredeljenje kompanije i njenu odluku da izabere i primenjuje odgovarajuće poslovne prakse koje doprinose zajednici. Koncept korporativne društvene odgovornosti je danas standardizovan i predstavlja sastavni deo integrisanih sistema menadžmenta. On se primenjuje na domaćem tržištu od početka procesa ekonomske tranzicije, uglavnom u kompanijama koje su privatizovane stranim kapitalom. Ovaj rad prikazuje model za poboljšanje korporativne društvene odgovornosti (CSR) u domaćim poslovnim organizacijama, kao rezultat ispitivanja stavova menadžera u domaćim kompanijama o pitanjima koja se tiču korporativne društvene odgovornosti.

\section{Ključne reči:}

korporativna društvena

odgovornost, poslovna izvrsnost, konkurentnost, kvalitet, poslovanje.

Received: May 21st, 2012

Correction: June 22nd, 2012

Accepted: July 3rd, 2012 